\title{
Rilievo digitale integrato e documentazione delle quadrature all'interno della chiesa di Santa Teresa a Piacenza
}

\author{
Anastasia Cottini \\ Roberta Ferretti
}

Abstract

Il presente articolo sintetizza le operazioni di rilievo digitale integrato e documentazione dell'apparato decorativo della chiesa di Santa Teresa a Piacenza, con particolare riferimento alle quadrature dipinte dai Natali. Vengono presentati brevi cenni storici riguardo all'origine e la diffusione del Quadraturismo, per poi illustrare le metodologie adottate in fase di acquisizione ed elaborazione dati. Vengono infine esposte le potenzialità di questa tipologia di rilievo, applicata al caso studio.

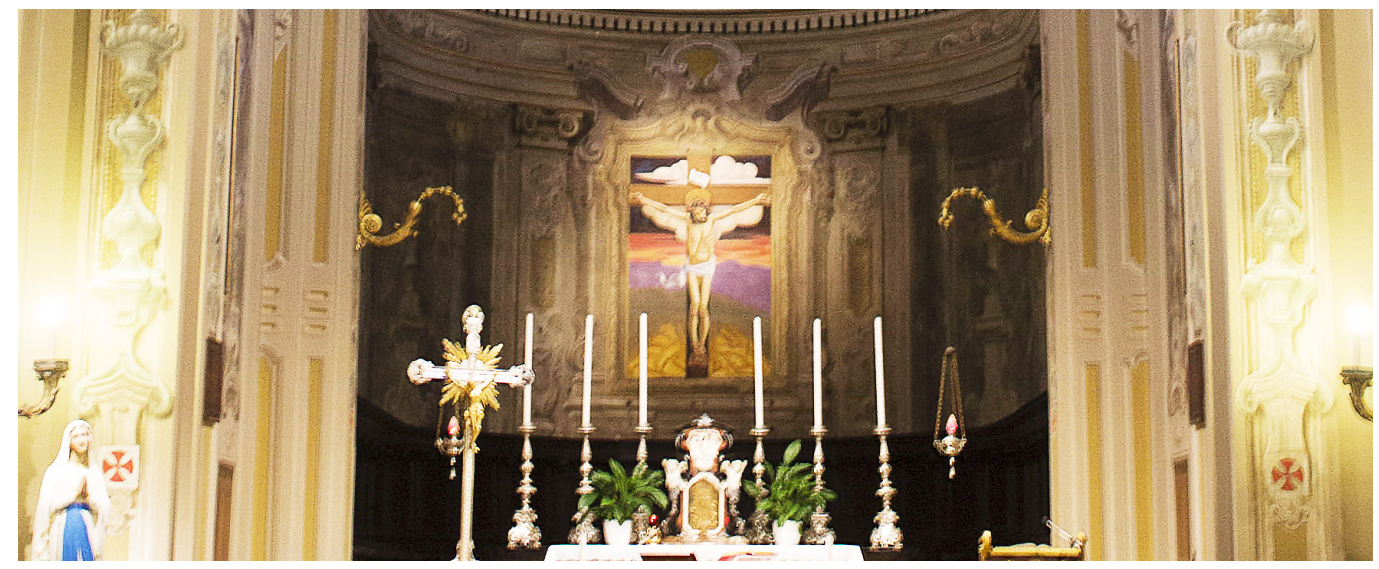




\section{Introduzione}

Il presente articolo riassume le operazioni di documentazione tramite rilievo digitale integrato e di elaborazione dei dati della chiesa di Santa Teresa a Piacenza, svolte nell'ambito di un seminario tematico del corso di Rilievo dell'Architettura del Dipartimento di Architettura - Università degli Studi di Firenze e di una successiva tesi di Laurea. Le operazioni di rilievo sono state condotte nel maggio 2019 da un team di studenti e dottorandi, con la finalità di acquisire dati in merito all'apparato decorativo della chiesa, appartenente al genere pittorico del Quadraturismo. Quanto acquisito è stato poi rielaborato per ottenere rappresentazioni bidimensionali dello stato di fatto, le quali sono state utilizzate come base di partenza per ulteriori studi sul caso-studio e per confronti con casi-studio simili.

\section{Quadraturismo: brevi cenni}

Nel corso del Cinquecento il Quadraturismo si attesta come genere pittorico autonomo: la pittura murale di architetture illusorie vede infatti il suo massimo sviluppo durante l'epoca barocca, pur trovando antecedenti nelle riproduzioni prospettiche della realtà nell'arte greca e pompeiana e nello studio della prospettiva di età Rinascimentale [Del Duca 20 I5, p. 14]. La definizione propria di 'quadratura' [I], rispetto a quella di "pittura murale di architetture illusorie", resta incerta, anche se è possibile accettare come valida la puntualizzazione che vede il Quadraturismo come la rappresentazione di architetture in prospettiva con lo scopo di superare i limiti dell'ambiente reale, ingannando l'occhio e moltiplicando illusionisticamente lo spazio, combinando elementi pittorici ed architettonici all'interno di spazi immaginari ma ragionati [Mele 2020].

II successo di tale tecnica pittorica è dovuto principalmente al carattere fastoso ed all'abbinamento tra scienza della prospettiva e sistema degli ordini architettonici; è arte dell'illusione poiché evoca spazi ed immagini dove la struttura edilizia offre solo il limite invalicabile della parete. La nascita ed il repentino successo di questo genere pittorico si spiegano perché la "progettazione dell'inganno", in cui realtà e finzione si mescolano, suscita nello spettatore grande stupore e meraviglia ed è legata alla poetica del Barocco. Oltre a ciò, vi è il fattore economico: il Quadraturismo, infatti, garantisce sontuosità e fasto avvalendosi di materiali dal costo modesto a fingere elementi architettonici che, se reali, renderebbero necessaria una profusione di marmi e materiali molto costosi.

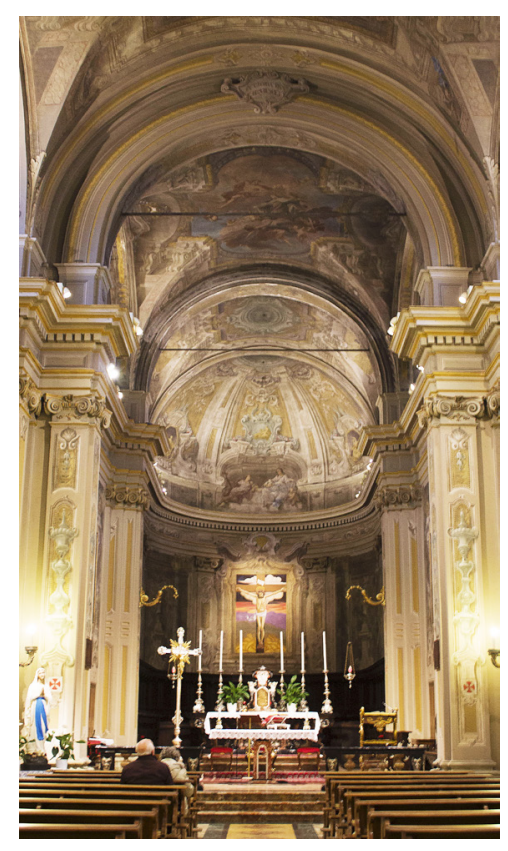


Nel corso del Seicento, inoltre, si assiste ad importanti cambiamenti nel panorama culturale a causa della Controriforma: il linguaggio comunicativo della Chiesa si rinnova allo scopo di coinvolgere maggiormente i fedeli, in difesa dell'ortodossia cattolica contro l'eresia protestante, e l'arte figurativa e l'architettura religiosa divengono celebrazione di Dio e dei Santi [2]. Si iniziano ad affermare dunque artisti specializzati, chiamati "pittori di architettura" o "pittori di quadratura", la cui formazione comprende necessariamente, oltre alle regole della pittura, anche quelle del disegno geometrico ed architettonico. Essi operano in collaborazione con "pittori di figura" nella realizzazione di grandi cicli decorativi in cui l'architettura dipinta funge da collegamento tra lo spazio reale in cui si colloca e quello immaginario nel quale è situata la scena figurativa. Vengono pubblicati trattati che contribuiscono alla diffusione delle teorie sulla prospettiva, sulle regole di rappresentazione e sulle tecniche di trasferimento del disegno bidimensionale dal cartone preparatorio alla superficie architettonica - tra questi ricordiamo quelli diVignola ( I 583, con lunghi commentari di E. Danti), di Troili ( 1683 ), di Pozzo (1693), di Palomino (I 723) [Mele 2020]. A loro volta, questi trattati non possono prescindere dalla trattatistica precedente di Vitruvio, Alberti, Dürer, Serlio [Martinelli Braglia 2004].

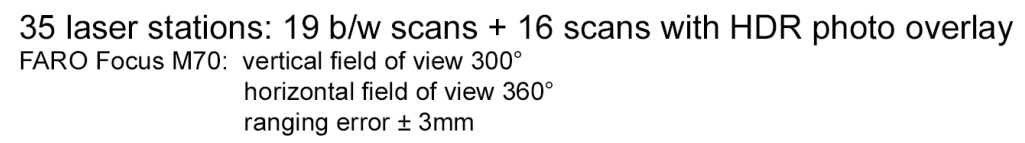

- Laser stations Q Unexamined area

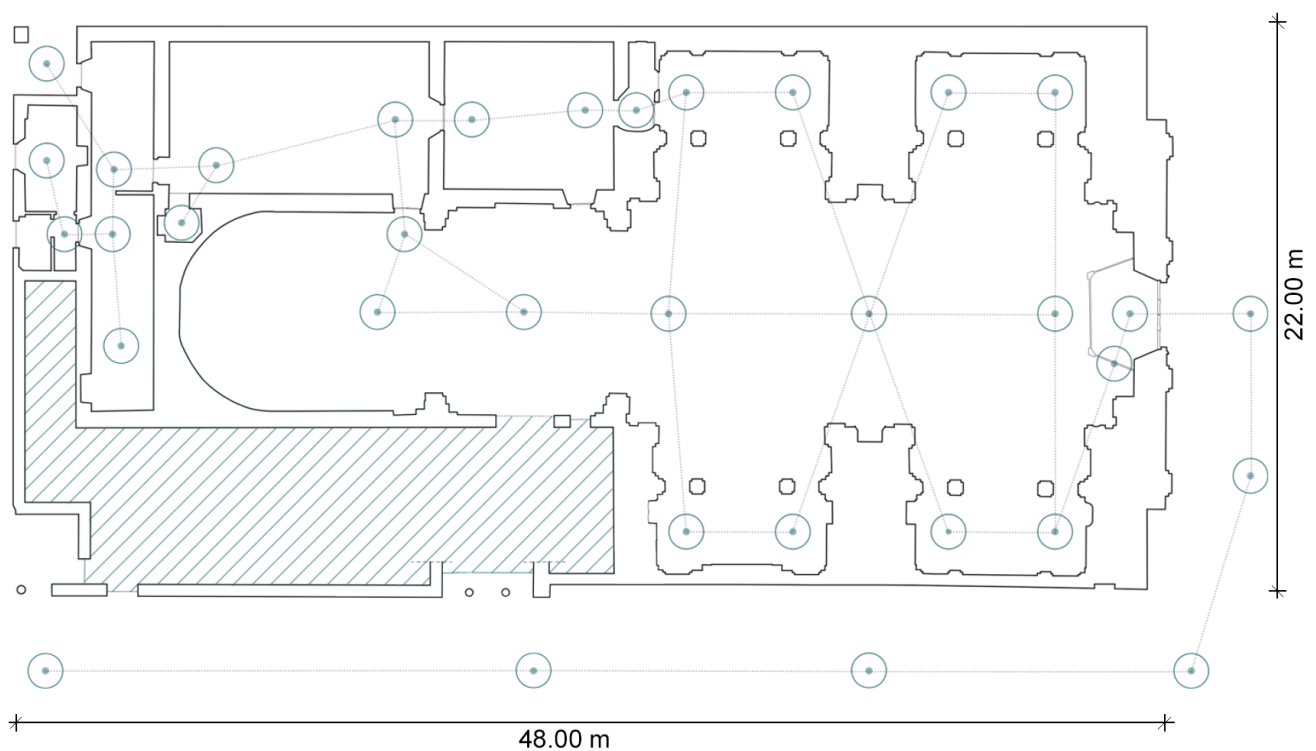

\section{Quadraturismo in Emilia-Romagna ed a Piacenza}

Nei primi decenni del Seicento, Bologna si trova ad essere sede privilegiata di applicazione delle quadrature, grazie alla committenza del cardinale Spada ed all'opera di Curti, Colonna, Mitelli e Martinelli [Amoruso, Manti 2020], mentre a Parma sono attivi Ricci,Valmagini e Ferdinando Galli Bibiena [3] [Prati 2020]. Degli ultimi due è attestata l'attività anche a Piacenza (Oratorio di San Cristoforo, scenografie per il Teatro Ducale di Cittadella), dove operano principalmente i cremonesi Giuseppe, Francesco e Giambattista Natali, che tengono ben presenti le soluzioni stilistiche di F. Galli Bibiena ma anche di Colonna e Mitelli. 
Lo stile di Francesco Natali è caratterizzato dalla rappresentazione di balaustrini, volute, conchiglie, foglie d'acanto, mensoloni che si dipartono da cornici mistilinee, festoni vegetali: elementi riscontrabili a Piacenza nelle decorazioni della cappella di Sant'Antonio nella chiesa di Santa Teresa, dell'oratorio di San Giorgio in Sopramuro, della chiesa delle Teresiane. Ciò porta ad ipotizzare che l'artista abbia riutilizzato gli stessi cartoni, adattandoli di volta in volta ai diversi ambienti. Mentre le quadrature di Francesco e Giuseppe Natali raffigurano spazi virtuali ma sempre impostati in modo da risultare percorribili, quelle del più giovane Giambattista si discostano da tale tendenza, a favore di un intento maggiormente decorativo ed illusorio. La lezione di Francesco Natali viene ereditata da Zaist e dai Magri, attivi a Piacenza e Napoli [Còccioli Mastroviti 2020].

Tra le opere di Francesco Natali nel piacentino sono degli esempi le quadrature all'interno delle già citate chiesa delle Teresiane, chiesa di San Giorgio Sopramuro e cappella di Sant'Antonio nella Chiesa di Santa Teresa, oltre a quelle di alcune stanze del palazzo Cavazzi della Somaglia, delle chiese di San Rocco, San Vincenzo e San Giovanni in Canale e del palazzo Bertamini-Lucca a Fiorenzuola d'Arda [Còccioli Mastroviti Anna (20 I I), Per il quadraturismo a Cremona e nel territorio: committenti, artisti, cantieri, in Artisti cremonesi. II Settecento, Cremona.

1. ALIGN PHOTOS

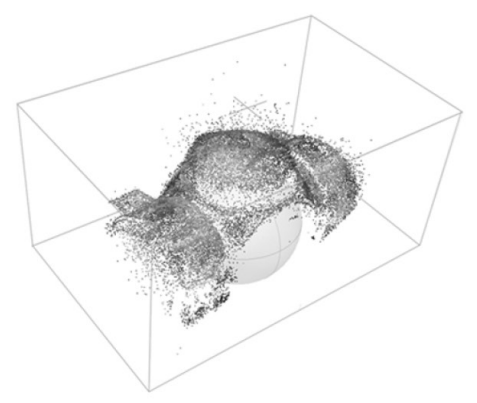

3. BUILD MESH

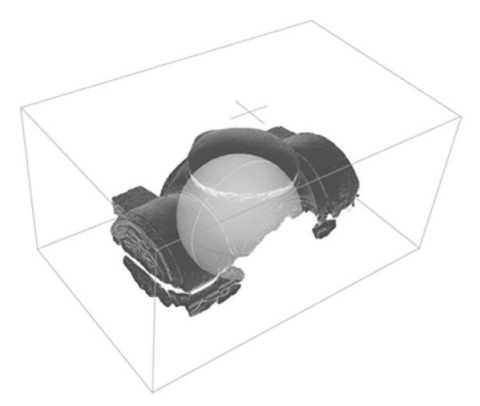

2. BUILD DENSE CLOUD

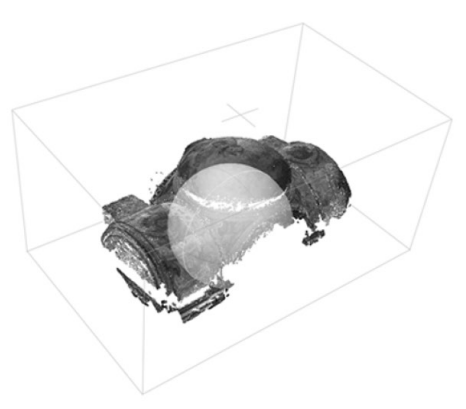

4. BUILD TEXTURE

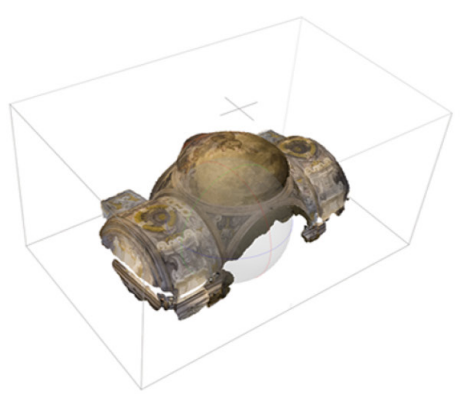

5. BUILD ORTHOMOSAIC

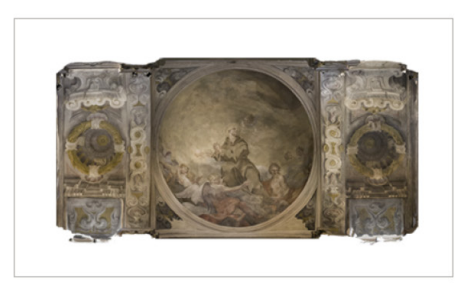




\section{La chiesa di Santa Teresa a Piacenza}

La chiesa di Santa Teresa è edificata nel centro storico di Piacenza, nel luogo in cui, all'inizio del I 300 viene costruita dall'Ordine degli Umiliati una chiesa dedicata allo Spirito Santo. In seguito alla soppressione dell'Ordine degli Umiliati da parte di Pio V nel I57|, giungono a Piacenza i Carmelitani Scalzi ( 1626 ) che iniziano la costruzione della chiesa, a partire dal 1650.

In stile barocco, schema planimetrico basilicale a navata unica con cappelle laterali, presbiterio e abside, rappresenta un esempio raro, tra le chiese attualmente aperte al culto nella città di Piacenza, di decorazione pittorica di inizio Settecento. La facciata della chiesa si presenta sobria e ripropone la linearità classica cinquecentesca.

Allinterno, l'area presbiteriale e le cappelle sono decorate ad affresco con quadrature ad opera di Giuseppe e Francesco Natali e raffigurazioni per mano di Robert de Longe, Giovanni Angelo Borroni, Sebastiano Galeotti e Bartolomeo Rusca (prima metà del Settecento) [Còccioli Mastroviti 2020].

Nel 1746, quando Piacenza è coinvolta nella terza guerra di successione, la chiesa viene utilizzata come ospedale militare. Nel 1819 l'ordine religioso è soppresso a causa delle leggi napoleoniche.

La chiesa viene restituita al culto nel 1860 ed è oggetto di lavori di restauro effettuati nei primi anni Ottanta del $X X$ secolo, in occasione dei quali si riscopre la presenza della cripta al di sotto del coro (fig. I).
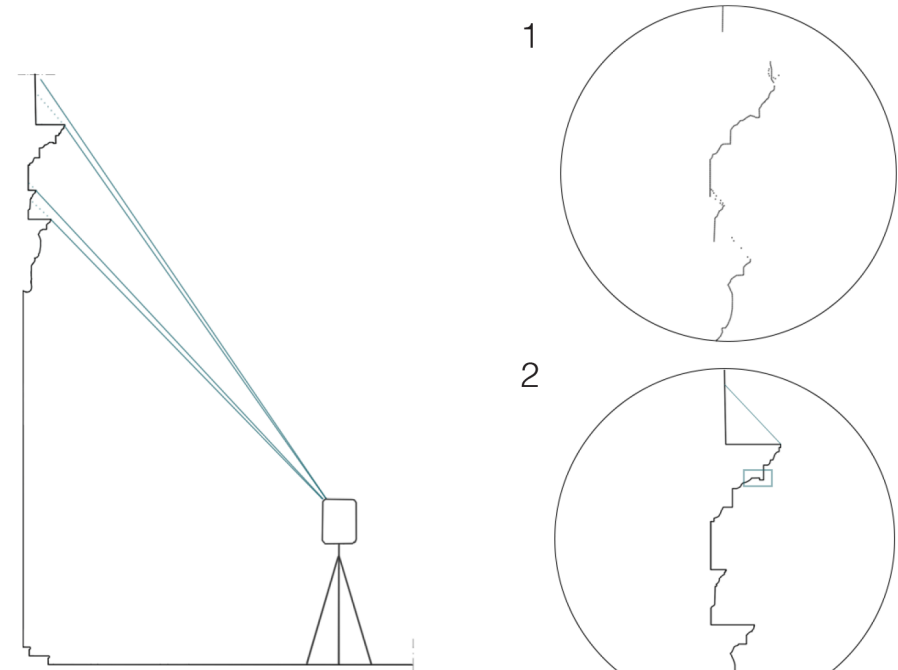

2

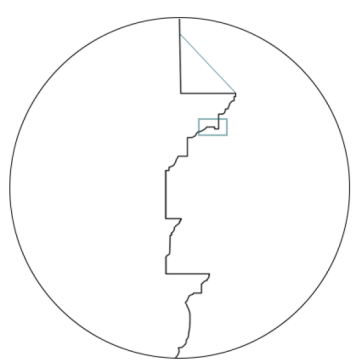

1. Point cloud data

2. Processed data

\section{Metodologie di acquisizione ed elaborazione dati}

La campagna di rilievo strumentale è stata preceduta da una fase di analisi in situ dell'oggetto da rilevare, al fine di elaborare un progetto di rilievo che prendesse in considerazione la morfologia dell'architettura e le finalità del rilievo stesso e prevedesse le eventuali difficoltà eventualmente riscontrate nelle fasi successive.

La finalità del rilievo era infatti quella di ottenere una documentazione quanto più completa dell'apparato decorativo pittorico della chiesa, senza ovviamente tralasciare il contesto architettonico all'interno del quale gli affreschi sono inseriti. Si è optato dunque per l'integrazione di nuvole di punti acquisite con laser-scanner e modelli mesh ottenuti da fotogrammetria 3D. 
II modello di laser-scanner utilizzato è il FARO M70, in grado di acquisire anche un dato fotografico da sovrapporre a quello della nuvola di punti. Le scansioni effettuate all'interno della chiesa, diversamente da quelle effettuate in esterno, comprendono il dato fotografico: questo ha comportato un aumento dei tempi di acquisizione delle singole scansioni, ma ha permesso di ottenere dati completi della componente relativa al colore. Il percorso descritto con lo strumento si è concentrato esternamente lungo tre delle quattro facciate della chiesa, in quanto la quarta si trova in aderenza ad altri edifici; internamente ci si è concentrati nell'acquisire un dato quanto più esaustivo della navata, delle cappelle laterali, dell'abside e del loro apparato decorativo (fig. 2). Le stanze della sacrestia, non presentando affreschi di particolare interesse, hanno richiesto una risoluzione delle singole scansioni minore, in modo da velocizzare le operazioni; la cripta non è stata rilevata. La maggiore criticità è derivata dalla presenza di numerosi visitatori e di elementi di arredo all'interno della chiesa, che hanno creato coni d'ombra e quindi assenza di dato nelle scansioni.

Per quanto riguarda la fotogrammetria 3D, ci si è concentrati all'interno della chiesa per acquisire con macchine fotografiche reflex dati riguardanti le pareti ed i soffitti affrescati. Le difficoltà principali hanno riguardato il corretto bilanciamento di apertura del diaframma, tempi di scatto ed ISO, a causa delle scarse condizioni di illuminazione della chiesa e della presenza di finestre attraverso le quali entrava la luce del sole.

I dati del laser-scanner sono stati elaborati con il software Leica Cyclone, per allineare le scansioni tra di loro in un comune sistema di riferimento, definendo corrispondenze tra i punti naturali omologhi mediante operazioni di rototraslazione, per creare un model space

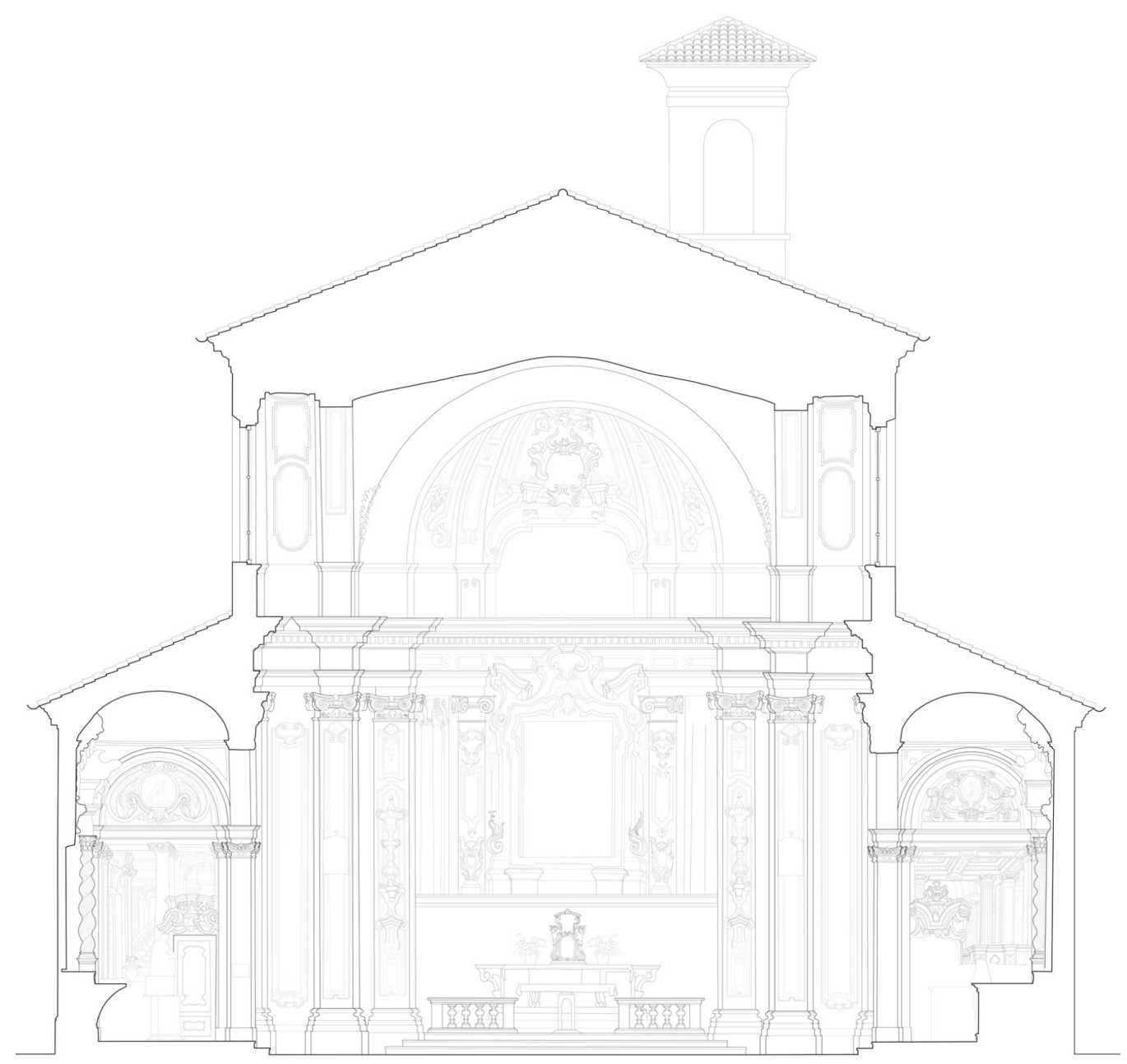


unico. La nuvola di punti tridimensionale ottenuta è stata successivamente manipolata attraverso il software al fine di ottenere delle viste ortogonali per l'acquisizione di orthoimmagini ad alta risoluzione, le quali, una volta mosaicate all'interno del programma Autodesk AutoCAD, hanno costituito la base per la realizzazione dei disegni di piante, sezioni e prospetti. Le fotografie acquisite da reflex sono state elaborate con il software 3DFlow Zephyr: il programma, aiutandosi con i file EXIF generati dalle fotocamere, ha individuato dei punti comuni tra le fotografie ed ha calcolato e determinato la posizione del punto di ripresa per ogni singola immagine. Come risultato di questa operazione si sono ottenute una nuvola rada di punti (sparse cloud), una nuvola di punti densa (dense cloud) ed una mesh (fig. 3). II modello tridimensionale è stato scalato ponendo manualmente dei marker in punti notevoli dell'oggetto, prendendo come riferimento la nuvola di punti aperta in Cyclone: ad ogni marker del modello fotogrammetrico sono state attribuite le coordinate $X Y Z$ del punto corrispondente nella nuvola di punti. II modello 3D scalato è stato poi texturizzato ed utilizzato per la creazione di orthomosaici. Gli elaborati bidimensionali sono stati ottenuti attraverso il disegno CAD effettuato sulla mosaicatura delle orthoimmagini (fig. 4). La mosaicatura è un disegno continuo, che ha permesso di leggere e rendere misurabili tutti gli elementi necessari alla comprensione dell'architettura. Ė stato rappresentato il disegno gerarchizzando gli elementi architettonici, in modo tale da poter approfondire, in base alla scala di rappresentazione, il livello di dettaglio richiesto (fig. 5). II passaggio successivo è stato quello della creazione di fotopiani a partire dagli orthomosaici. Gli orthomosaici ottenuti dall'elaborazione fotogrammetrica sono stati ripuliti mediante il programma Adobe Photoshop, sempre tenendo fisso il riferimento del disegno CAD. Oltre agli elaborati di pianta, sezioni e fotopiani, è stato prodotto un abaco che prenda in considerazione gli elementi decorativi caratteristici e che permetta di effettuare ulteriori analisi. A tale fine è importante ribadire l'importanza dell'affidabilità degli elaborati bidimensionali, a supporto dei quali sono state indispensabili le operazioni di rilievo digitale integrato e che hanno permesso di ottenere immagini ortorettificate anche delle superfici curve.
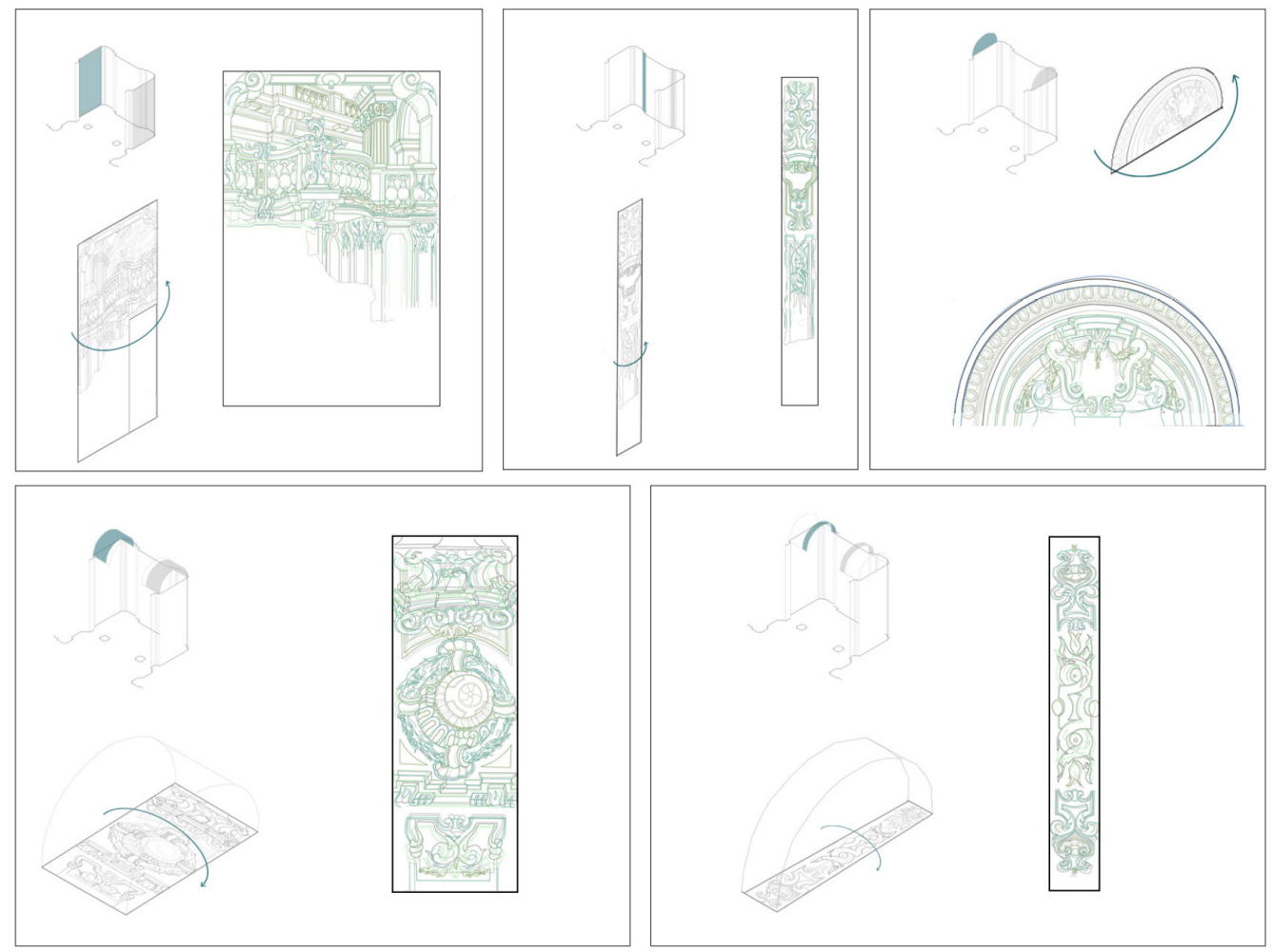


\section{Conclusioni}

Le operazioni di acquisizione ed elaborazione dati descritte nel presente articolo hanno consentito di ottenere una documentazione completa ed esaustiva riguardo l'apparato decorativo della chiesa di Santa Teresa a Piacenza, offrendo una base per ulteriori studi ed approfondimenti in merito. I dati elaborati possono infatti essere utilizzati per fare confronti tra le quadrature della chiesa di Santa Teresa e quelle presenti in altre chiese coeve di Piacenza (Chiesa delle Teresiane, Chiesa di San Giorgio Sopramuro), già oggetto di analisi in occasione di un seminario tematico del corso di Rilievo dell'Architettura del Dipartimento di Architettura - Università degli Studi di Firenze: ciò consente di formulare ipotesi relativamente agli autori dei dipinti, ai modelli utilizzati come riferimenti architettonici, alla presenza di cartoni utilizzati in più cantieri, ad eventuali parallelismi tra le architetture dipinte e quelle reali all'interno delle quali sono inserite.

In particolare, attraverso l'analisi delle quadrature della chiesa di Santa Teresa, si può ipotizzare che esse siano state eseguite con la tecnica della trasposizione del progetto decorativo sulle pareti tramite "incisione indiretta", utilizzando dei cartoni per eseguire lo spolvero. Per quanto riguarda le cappelle laterali, si può notare come il costrutto virtuale sia il medesimo per tutte, ma specchiato su di un lato rispetto all'altro, con finte cupole in prospettiva 'di sotto in su' sulle volte a botte e schemi prospettici non propriamente regolari sulle pareti [4] (fig. 6). Anche per la navata centrale probabilmente sono stati utilizzati i medesimi cartoni, ricombinati tra di loro in modo da adattarsi alle singole campate, le quali presentano ciascuna un impianto prospettico autonomo (fig. 7).

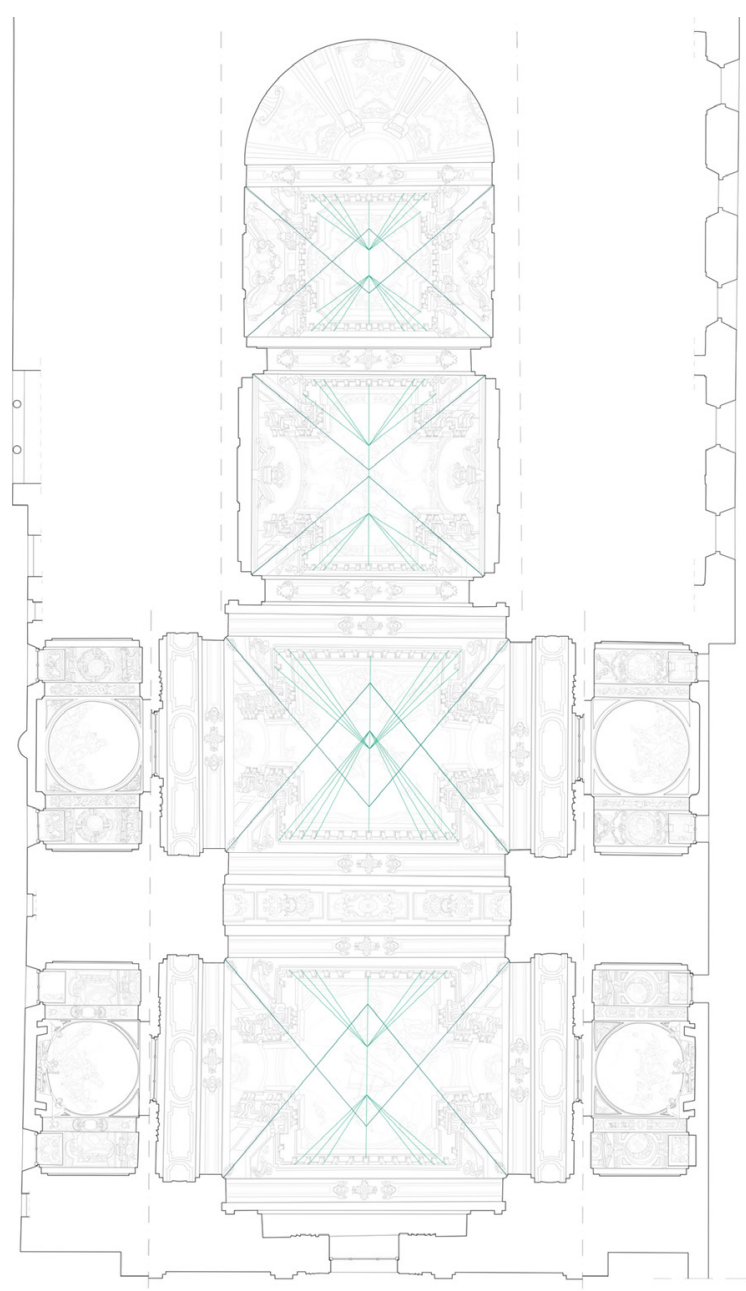




\section{Note}

[I] Tale termine viene introdotto per la prima volta nel 1666 da A. Masini [Amoruso, Manti 2020].

[2] Si vedano esempi emblematici quali la scultura dell'Estasi di Santa Teresa d'Avila del Bernini per quanto riguarda l'arte figurativa e la chiesa del Gesù di Roma di Vignola/Buonarroti/Della Porta per quanto riguarda l'impianto tipico tridentino.

[3] Ferdinando Galli Bibiena avvia la Scuola di Architettura dell'Università di Bologna nel I7I9 [Martinelli Braglia 2004].

[4] Probabilmente ciò è dovuto all'impiego di cartoni già utilizzati altrove ed assemblati in occasione della realizzazione di tali scene.

\section{Riferimenti bibliografici}

Capurso Gianluca, Martire Francesca (2015). "Buongiorno, signori. lo sono un elaboratore ELEA 9000". Calcolo automatico e progettazione strutturale. In Martire Francesca (a cura di). Storia dell'ingegneria strutturale in Italia - SIXXI 2. Roma: Gangemi Editore, pp. 98-110

Di Palma Wilma (1999). Un Museo della Matematica: Utopia o realtà possibile. In Di Palma Wilma (a cura di). I racconti di Numeria. Guida alle collezioni di modelli matematici del Comune di Roma. Roma: Argos, 10 pp.

Hilbert David, Cohn-Vossen Stefan (1972). Geometria Intuitiva. (Traduzione di Adolfo Verson). Torino: Bollati Boringhieri. (Ed. orig. Anschauliche Geometrie Einfachste Grundbegriffe der Topologie. Berlin: Springer-Verlag, 1932).

Imperiale Alicia (20 I8). An 'Other' Aesthetic: Moretti's Parametric Architecture. In LOG, 44, pp. 7I-82.

Loria Gino (1935). Metodi matematici. Milano: Hoepli.

Palladino Nicla, Palladino Franco (2008). I modelli matematici costruiti per l'insegnamento delle matematiche superiori pure e applicate. In Ratio Mathematica, 19, pp. 31-88.

Pottmann Helmut et al. (2007). Architectural Geometry. Exton: Bentley Institute Press.

Vaudeville Bernard et al. (2013). How Irregular Geometry and Industrial Process Come Together: A Case Study of the "Fondation Louis Vuitton Pour la Creation", Paris. In Hesselgren Lars et al. (eds.). Advances in Architectural Geometry 20 I 2.Wien: Springer-Verlag, pp. 343.

Autori

Anastasia Cottini, Università degli Studi di Firenze, anastasia.cottini@unifi.it

Roberta Ferretti, Università degli Studi di Firenze, roberta.ferretti@stud.unifi.it

Per citare questo capitolo: Cottini Anastasia, Ferretti Roberta (2020). Rilievo digitale integrato e documentazione delle quadrature all'interno della chiesa di Santa Teresa a Piacenza/Integrated digital survey and documentation of the quadrature paintings in the Santa Teresa Church in Piacenza In Arena A., Arena M., Brandolino R.G., Colistra D., Ginex G., Mediati D., Nucifora S., Raffa P. (a cura di). Connettere. Un disegno per annodare e tessere. Atti del $42^{\circ}$ Convegno Internazionale dei Docenti delle Discipline della Rappresentazione/Connecting. Drawing for weaving relationships. Proceedings of the 42th International Conference of Representation Disciplines Teachers. Milano: FrancoAngeli, pp. 2012-2029. 


\section{Integrated Digital Survey and Documentation of the Quadrature Paintings in the Santa Teresa Church in Piacenza}

Anastasia Cottini

Roberta Ferretti

Abstract

This paper summarises the operations of integrated digital survey and documentation of the decorative elements of the Santa Teresa Church in Piacenza, especially of the Natali's quadrature. Brief historical notes about Quadraturismo's origins and dissemination are presented, then the data acquisition and processing methodologies are explained. The possibilities of this survey typology, applied to the present case-study, are showed.

quadraturismo, integrated digital survey, documentation, perspective.

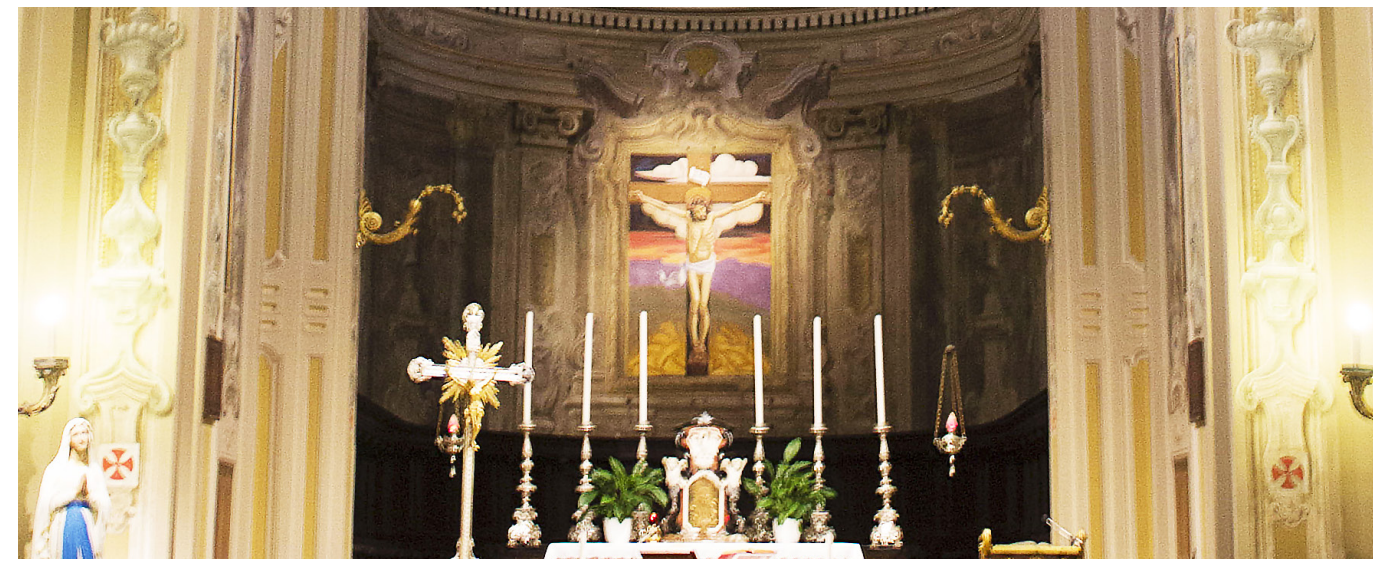




\section{Introduction}

This article summarises the Digital Survey and the elaboration of the data of Santa Teresa's Church in Piacenza carried out during a thematic workshop of the Laboratorio di Rilievo dell'Architettura - University of Florence and a subsequent degree thesis. The Digital Survey was conducted in May 2019 by a team of students and Ph.D. students, to acquire data on the decorative elements of the church, belonging to the pictorial genre of Quadraturismo. The data elaboration had as its objective the creation of a two-dimensional representation of current situation of the church, which has been used as a basis to study this particular case-study and for comparison with other case studies.

\section{Quadraturismo: brief references}

During the sixteenth century, the Quadraturismo affirms itself as an independent pictorial genre: the painting of illusory architecture had its maximum development during the Baroque era while finding previous examples in the perspective reproductions of the reality in Greek and Roman art and the Renaissance prospective studies [Del Duca 20 I5, p. I4]. The definition of 'quadrature' [I], compared to the "painting of illusory architecture" remains uncertain, even if is possible to accept the clarification that underlines the Quadraturismo's purpose to overcome the limits of the real space, tricking the eye and multiplying illusionistically the space, by the combination of pictorial and architectural elements in imaginary, but well thought, spaces. The success of this pictorial genre is mainly due to its sumptuous effect and to the combination of the science of perspective and the architectural orders system; it is called "art of illusion" because it evokes images and spaces where the building structure only offers the limit of the wall.

The creation and the sudden success of this pictorial genre can be explained by the great amazement that the "project of deception", in which reality and fiction are mixed, raises in the viewer, this idea of wander is closely linked to the poetics of the Baroque style. In addition to this there is the economic factor: the Quadraturismo guarantee sumptuousness through the use of low-cost materials to represent architectural elements which, if real, would require the use of marble and other expansive materials.

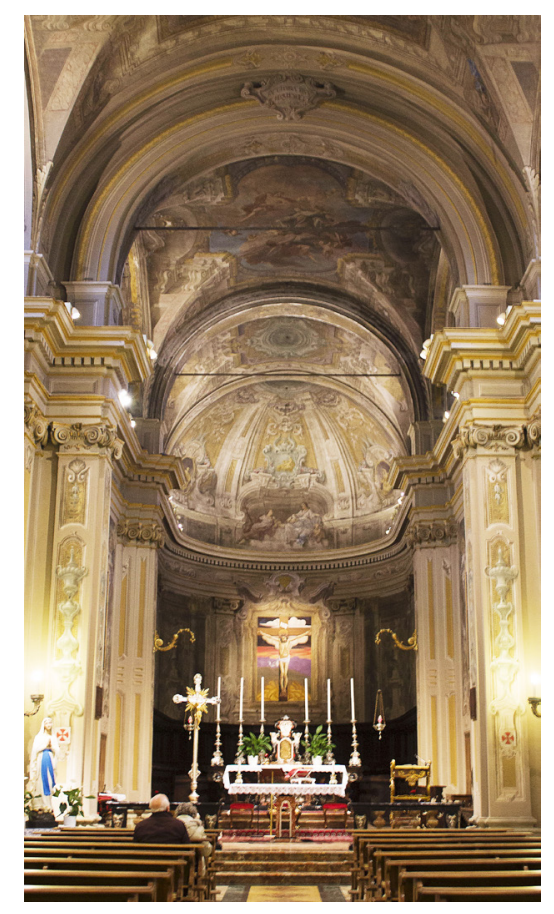


During the 18th century some important changes took place in the cultural environment as a result of the Catholic-Reformation: the communicative language of the Church was renewed to involve the faithful more and in defense of the Catholic orthodoxy against the heresy of the Protestantism. The figurative art and the religious architecture became a way to celebrate God and the Saints [2].

At the same time begun to establish specialized painters called "painters of architecture" or "painters of quadratura" whose education necessary included, in addition to the rules of painting also those of the architectural and geometric drawing. They were operating in collaboration with "figure painters" in the realization of decorative cycles in which the painted architecture was the connecting element between the real space and the imaginary space in which the figurative scene was placed. The publication of treatises contributed to the spread of the theories about perspective, rules of representation and two-dimension drawing transfer techniques from the preparatory cartoon to the architectural surface including the treaty by Vignola (I 583), Troili ( 683 ), Pozzo (1693), Palomino (I723) [Mele 2020]. Also these treaties cannot disregard the earlier treatise of Vitruvio, Alberti, Dürer, Serlio [Martinelli Braglia 2004].

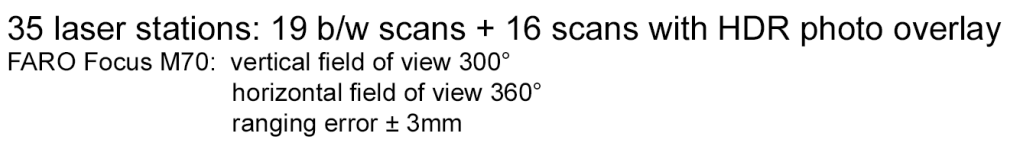

\section{- Laser stations Q Unexamined area}

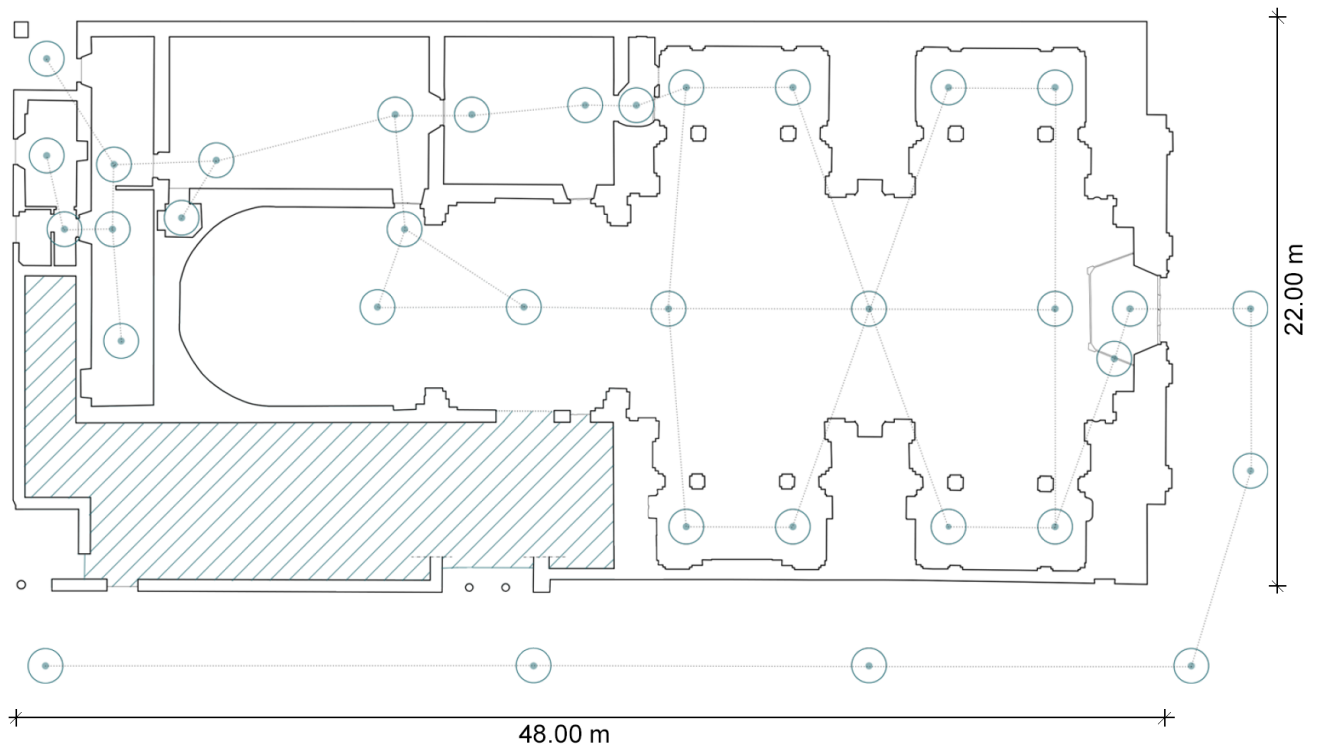

\section{Quadraturismo in Emilia Romagna and Piacenza}

In the early decades of I 8th century, the city of Bologna starts to be considered a privileged spot for the realization of "quadrature" paintings, due to the Cardinal Spada's requests and to the work of Curti, Colonna, Mitelli e Martinelli [Amoruso, Manti 2020], meanwhile in Parma were active artists like Ricci, Valmagini e Ferdinando Galli Bibiena [3] [Prati 2020]. The last two artists also worked in Piacenza (St. Cristoforo's Oratory, scenographies for the Teatro Ducale di Cittadella), where were primarily active Giuseppe, Francesco e Giovan Battista Natali from Cremona, in whose work is clear their knowledge of the stylistic solutions implemented by F. Galli Bibiena, A. Mitelli and M. Colonna. 
Francesco Natali's style is characterized by the representation of balustrades, spirals, shells, acanthus leaves, corbels departing from mixtilinear cornices, vegetal festoons: these decorative elements can be found also in Piacenza in the Chapel of St. Anthony in Santa Teresa's Church, in the oratory of San Giorgio Sopramuro and the Teresiane's Church. This leads to the hypothesis that the artist has reused the same preparatory cartoons adapting them, as the need arises, to the different spaces. Francesco and Giuseppe Natali's works are characterized by the representation of virtual spaces designed to be walkable, those of the younger Giovan Battista, on the other hand, move away from this trend in favor of a more decorative and illusory intent. Francesco Natali's lesson was inherited from Zaist and the Magri, artists active in Piacenza and Naples.

Examples of the Francesco Natali's works in Piacenza can be found in the pictorial system of the already mentioned Teresiane's Church, San Giorgio Sopramuro's Oratory and the Chapel of St. Anthony in Santa Teresa's Church and, in addition, in some rooms of Cavazzi della Somaglia's Palace, in the Churches of St. Rocco, St. Vincent and St. Giovanni in Canale and the Bertamini-Lucca's palace in Fiorenzuola d'Arda [Còccioli Mastroviti Anna (20 I I), Per il quadraturismo a Cremona e nel territorio: committenti, artisti, cantieri, in Artisti cremonesi. Il Settecento, Cremona].

\section{ALIGN PHOTOS}

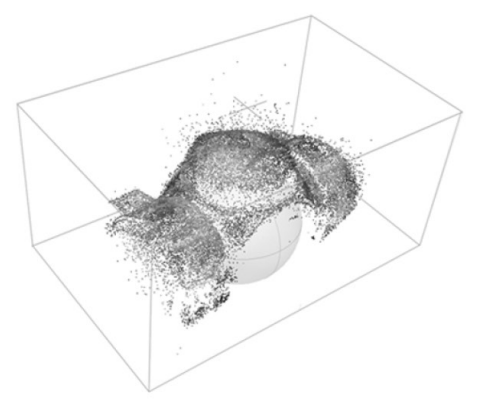

3. BUILD MESH

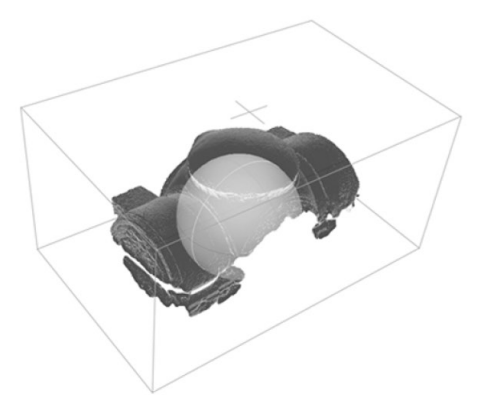

2. BUILD DENSE CLOUD

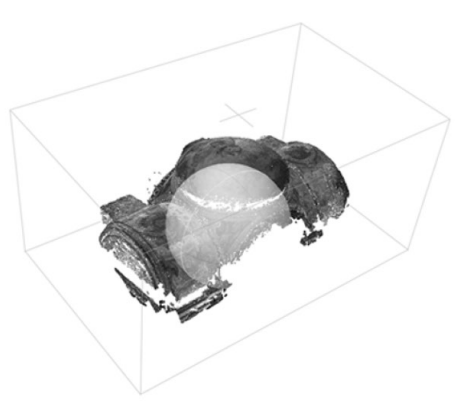

4. BUILD TEXTURE

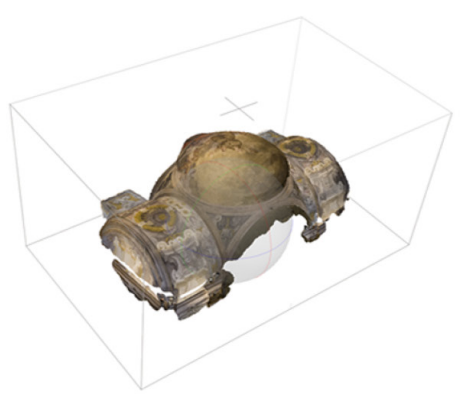

5. BUILD ORTHOMOSAIC

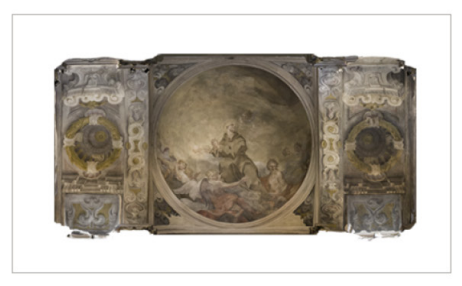




\section{The Church of Santa Teresa in Piacenza}

The Church of Santa Teresa is built in the historic center of Piacenza, in the place where at the beginning of I 300 a church dedicated to the Holy Spirit was built by the Order of the Humiliated. After the suppression of the Order of the Humiliated by Pope Pio V in 1571, the Carmelitani Scalzi Order (1626) arrived in Piacenza and began the construction of the church in 1650. In Baroque style, a singlenave basilica plan with side chapels, presbytery, and apse, this church is a rare example, among the churches currently open for worship in the city of Piacenza, of pictorial decoration of the early eighteenth century. The facade is sober and proposes the classical linearity of the sixteenth century. Inside, the presbytery and the chapels are decorated with "quadrature" frescoes by Giuseppe and Francesco Natali and representations by Robert de Longe, Giovanni Angelo Borroni, Sebastiano Galeotti and Bartolomeo Rusca (first half of the eighteenth century) [Còccioli Mastroviti 2020]. In I746, when Piacenza was involved in the Third Succession War, the church was used as a military hospital. In 1819 the religious order was suppressed due to Napoleonic laws. The church is returned to worship in 1860 and it was the object of restorative measures carried out in the early eighties of the twentieth century, during which these works was rediscovered a crypt below the choir (fig. I).
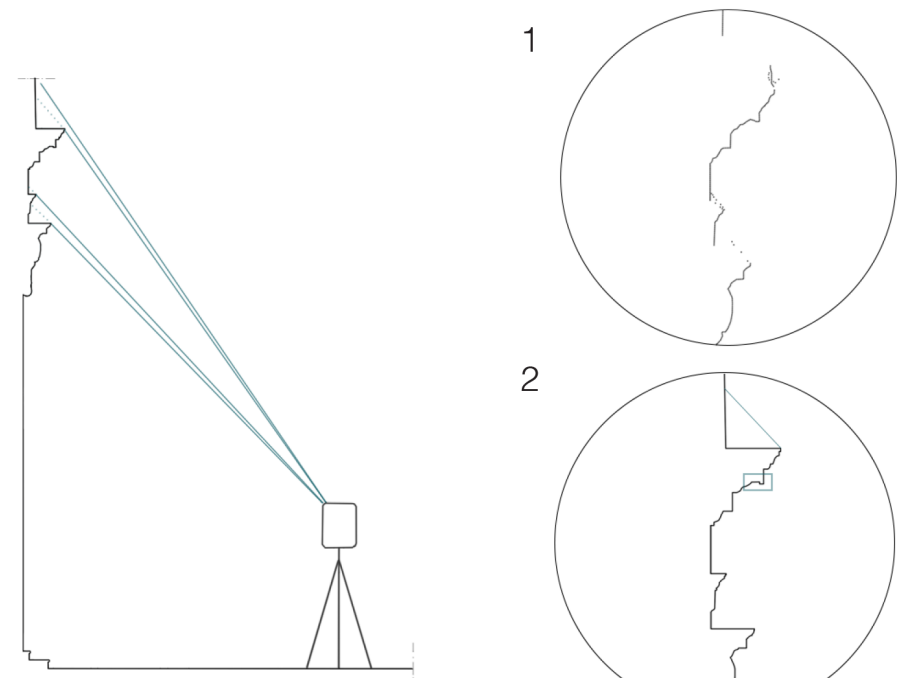

2

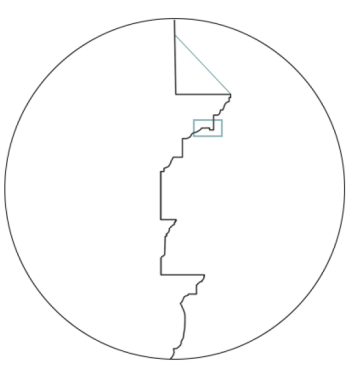

1. Point cloud data

2. Processed data

\section{Data acquisition and processing methodologies}

The digital survey campaign was preceded by an in situ analysis of the object, to draw up a survey project to take into account the morphology of the architecture, the purpose of the survey and to predict any difficulties that could be encountered at later stages.

The purpose of the survey was to obtain documentation as complete as possible of the decorative pictorial apparatus of the church, without neglecting the architectural context within the frescoes are inserted. Has been using the integration of the point cloud acquired with laser-scanner and mesh models obtained from 3D photogrammetry. 
The laser-scanner used is the FARO M70, which can also capture a photographic data to be superimposed on point cloud's one. The scans carried out inside the church, unlike those carried out out-side, include the photographic data: this has led to an increase in the time of acquisition of the individual scans, but has made it possible to obtain complete data of the color component. The path done with the instrument has involved externally three of the four facades of the church, because the fourth is in adherence to other buildings; internally we have concentrated in acquiring as much data as possible of the central nave, the side chapels, the apse, and their decorative apparatus (fig. 2). The rooms of the sacristy, with no frescoes of particular interest, required a minor resolution of the individual scans, in order to speed up operations; the survey of the crypt was not done. The most relevant criticism is derived from the presence of numerous visitors and furniture elements inside the church, which have created shadow cones and the consequent lack of data in the scans. The 3D photogrammetry was done only inside the church to acquire with reflex cameras data about the frescoed ceilings and walls. The main difficulties were the correct balancing of aperture, shutter speeds, and ISO, due to the poor lighting conditions of the church and the presence of windows through which sunlight entered. Laser-scanner data were processed with the Leica Cyclone software, to align scans in a common reference system, defining correspondences between homologous natural points by roto-translation, to create a single model space. The point cloud obtained was subsequently manipulated through the software to obtain orthogonal views for the acquisition of high-resolution orthoimages, which once

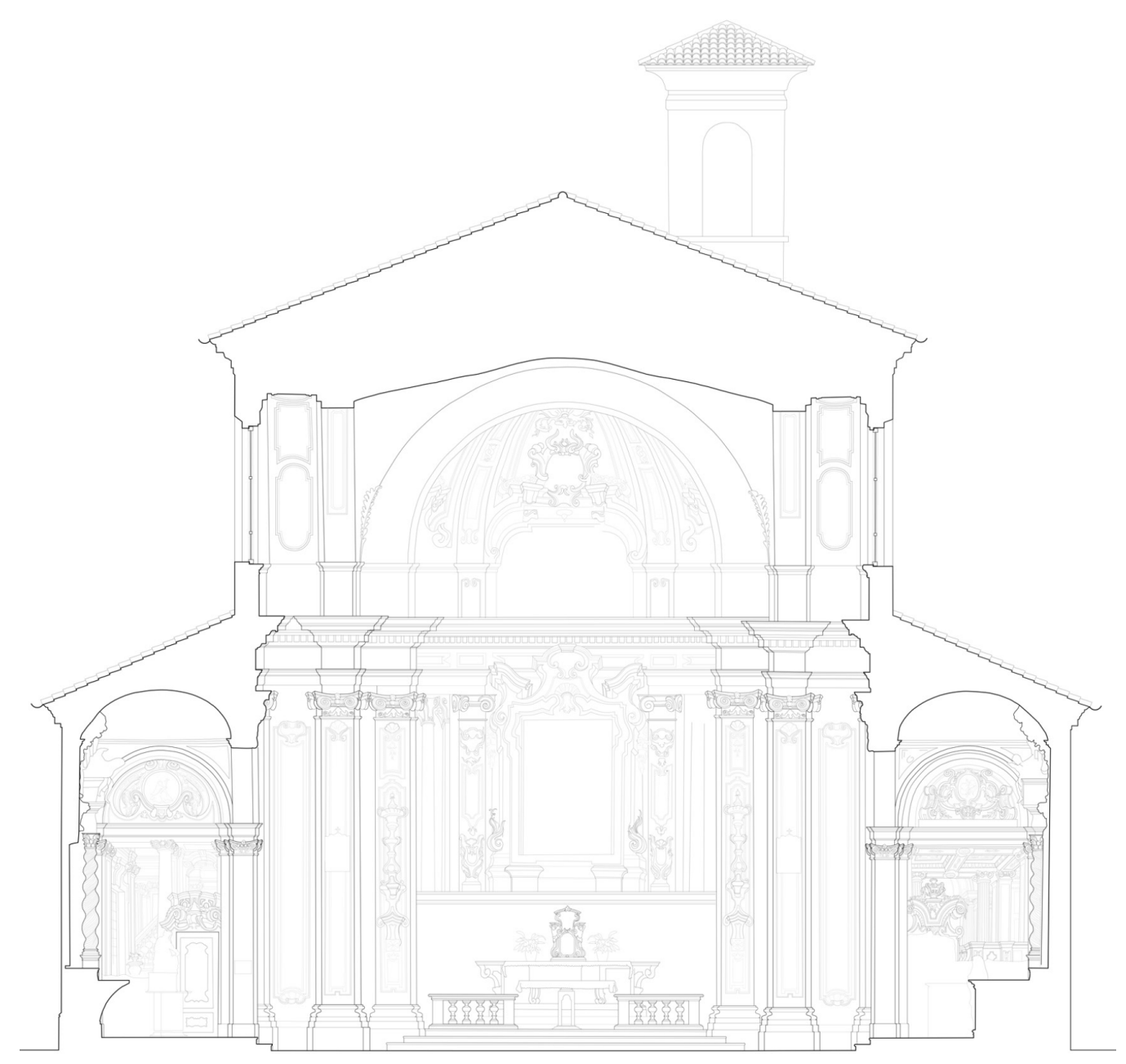


aligned within the program Autodesk Autocad, were the basis for the drawing of plans, sections, and elevations. The photos captured by reflex were processed with the software 3DFlow Zephyr: this program, using the EXIF files generated by the cameras, identifies the common points between the photos and calculates and determines the position of the point of view for each image. As a result of this operation have been obtained a sparse cloud, a dense cloud, and a mesh (fig. 3). The 3D model has been scaled through the manual marker positioning in remarkable points of the object taking as reference the point cloud opened in Cyclone: for every marker of the photogrammetric model has been assigned the $X Y Z$ coordinates of the corresponding point in the point cloud. The scaled 3D model was then texturized and used for the creation of ortho-mosaics. The two-dimensional representations were obtained though the CAD draw carried out on the mosaicing of the orthoimages (fig. 4). The mosaicing is a continuous drawing that enabled the comprehension and made measurable all the necessary elements of the architecture. In the final representation there was a hierarchy between the different architectural elements to have a deeper detail level according to the scale of representation (fig. 5). The next step was the creation of ortho-mosaics from the mosaicing of the orthoimages. The ortho-mosaic obtained by photogrammetric processing has been cleaned up using Adobe Photoshop, always keeping the $C A D$ drawing as reference.

In addition to plans, sections and ortho-mosaics have been produced an abacus to take into account the characteristic decorative elements and to make further analysis. It's important to underline the importance of the reliability of the two-dimensional drawings, trough the use of the integrated digital survey techniques it was also possible to obtain an orthorectified image of the curved surfaces too.
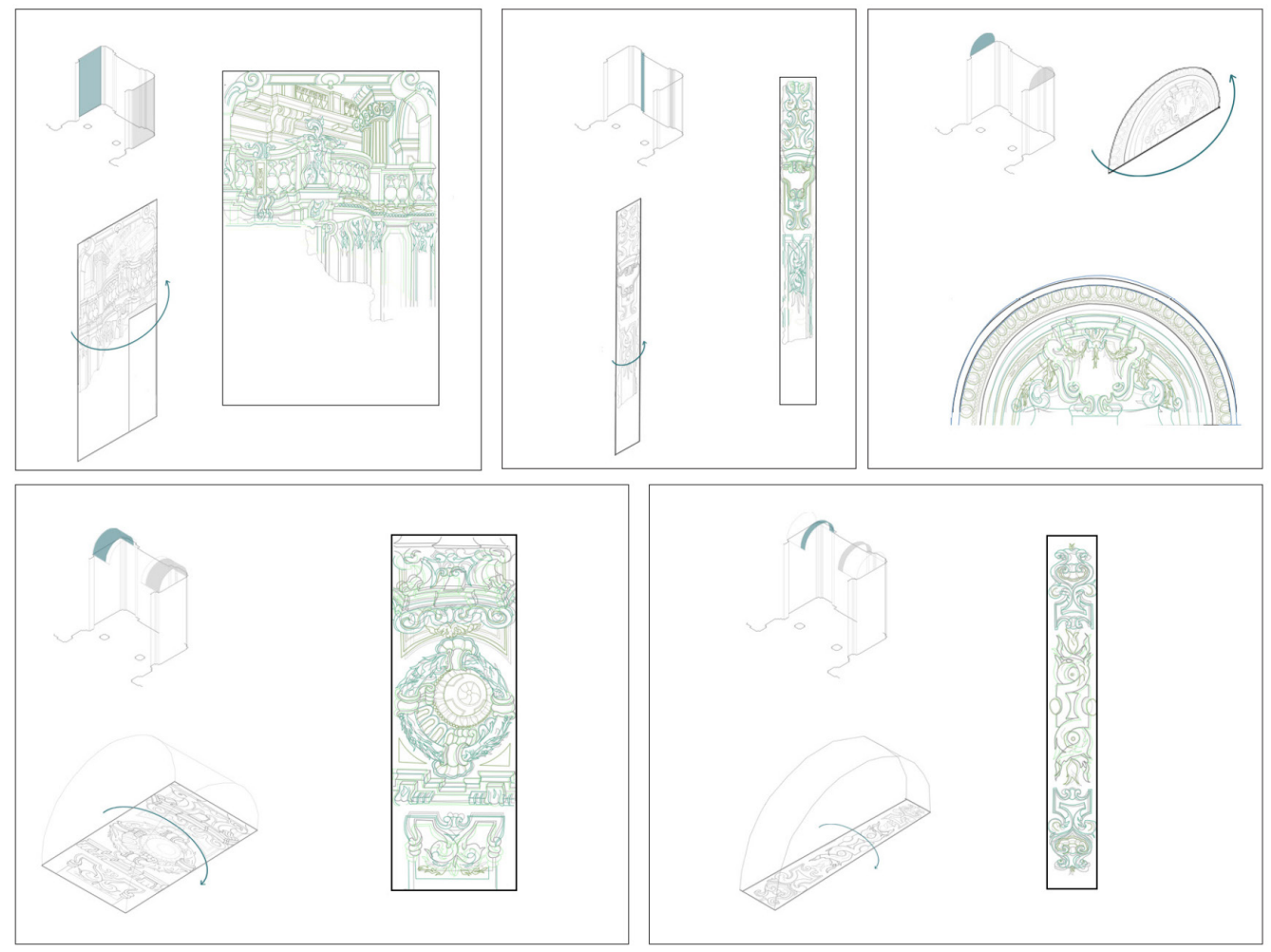


\section{Conclusions}

The data acquisition and processing operations described in this article have allowed to obtain a complete and exhaustive documentation regarding the decorative apparatus of the church of Santa Teresa in Piacenza, providing a basis for further studies. The data can be used to make comparisons between the 'quadratures' of the church of Santa Teresa and those present in other churches of Piacenza of the same age (Church of Teresiane, Church of San Giorgio Sopramuro), already object of analysis during the thematic workshop of the Laboratorio di Rilievo dell'Architettura - University of Florence: this enables to formulate a hypothesis about the authors of the paintings, to the models used as architectural references, to the presence of cartoons used in several sites, to possible parallelisms between the painted architectures and the real ones within which they are inserted.

In particular, through the analysis of the 'quadratures' of the church of Santa Teresa, it can be assumed that they were done with the technique of transposing the decorative project on the walls through "indirect engraving". As for the side chapels, it can be noted that the virtual construct is the same, but mirrored, for all the sidewalls, with fake domes in "from below" perspective on the barrel.

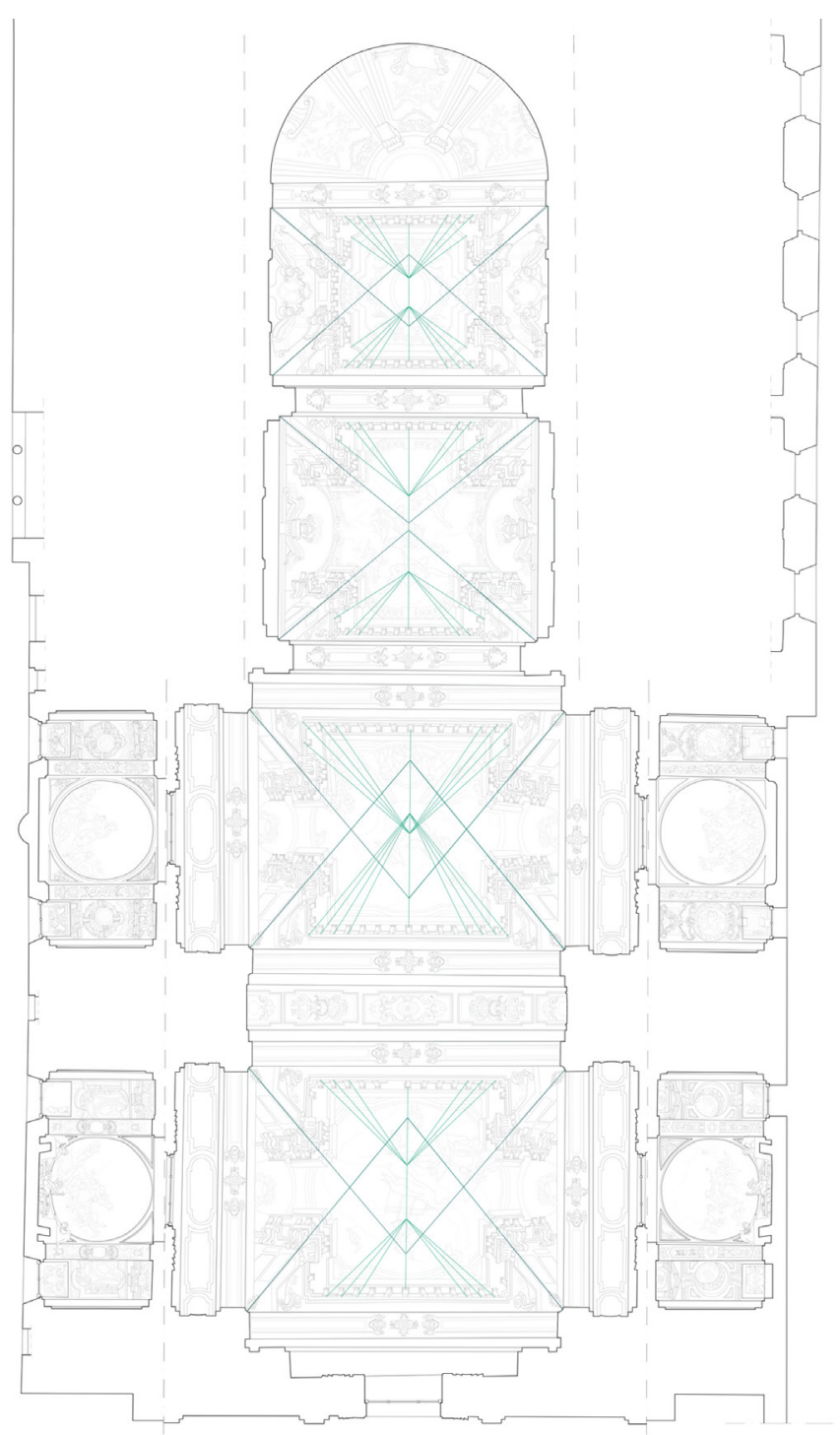




\section{Notes}

[I]Tale termine viene introdotto per la prima volta nel 1666 da A. Masini [Amoruso, Manti 2020].

[2] Si vedano esempi emblematici quali la scultura dell'Estasi di Santa Teresa d'Avila del Bernini per quanto riguarda l'arte figurativa e la chiesa del Gesù di Roma di Vignola/Buonarroti/Della Porta per quanto riguarda l'impianto tipico tridentino.

[3] Ferdinando Galli Bibiena avvia la Scuola di Architettura dell'Università di Bologna nel I7I9 [Martinelli Braglia 2004].

[4] Probabilmente ciò è dovuto all'impiego di cartoni già utilizzati altrove ed assemblati in occasione della realizzazione di tali scene.

\section{References}

Capurso Gianluca, Martire Francesca (2015). "Buongiorno, signori. lo sono un elaboratore ELEA 9000". Calcolo automatico e progettazione strutturale. In Martire Francesca (a cura di). Storia dell'ingegneria strutturale in Italia - SIXXI 2. Roma: Gangemi Editore, pp. 98-110.

Di Palma Wilma (1999). Un Museo della Matematica: Utopia o realtà possibile. In Di Palma Wilma (a cura di). I racconti di Numeria. Guida alle collezioni di modelli matematici del Comune di Roma. Roma: Argos, I0 pp.

Hilbert David, Cohn-Vossen Stefan (1972). Geometria Intuitiva. (Traduzione di Adolfo Verson). Torino: Bollati Boringhieri. (Ed. orig. Anschauliche Geometrie Einfachste Grundbegriffe der Topologie. Berlin: Springer-Verlag, 1932).

Imperiale Alicia (20 I8). An 'Other' Aesthetic: Moretti's Parametric Architecture. In LOG, 44, pp. 7I-82.

Loria Gino (1935). Metodi matematici. Milano: Hoepli.

Palladino Nicla, Palladino Franco (2008). I modelli matematici costruiti per l'insegnamento delle matematiche superiori pure e applicate. In Ratio Mathematica, 19, pp. 31-88.

Pottmann Helmut et al. (2007). Architectural Geometry. Exton: Bentley Institute Press.

Vaudeville Bernard et al. (2013). How Irregular Geometry and Industrial Process Come Together: A Case Study of the "Fondation Louis Vuitton Pour la Creation", Paris. In Hesselgren Lars et al. (eds.). Advances in Architectural Geometry 20 I 2. Wien: Springer-Verlag, pp. 343.

\section{Authors}

Anastasia Cottini, Università degli Studi di Firenze, anastasia.cottini@unifi.it

Roberta Ferretti, Università degli Studi di Firenze, roberta.ferretti@stud.unifi.it

To cite this chapter. Cottini Anastasia, Ferretti Roberta (2020). Rilievo digitale integrato e documentazione delle quadrature all'interno della chiesa di Santa Teresa a Piacenza/ Integrated digital survey and documentation of the quadrature paintings in the Santa Teresa Church in Piacenza. In Arena A., Arena M., Brandolino R.G., Colistra D., Ginex G., Mediati D., Nucifora S., Raffa P. (a cura di). Connettere. Un disegno per annodare e tessere. Atti del $42^{\circ}$ Convegno Internazionale dei Docenti delle Discipline della Rappresentazione/Connecting. Drawing for weaving relationships. Proceedings of the 42th International Conference of Representation Disciplines Teachers. Milano: FrancoAngeli, pp. 2012-2029. 